\title{
INVESTIGATIONS ON TEMPERATURE EFFECTS AND GERM RECOVERY FOR SOLAR WATER DISINFECTION (SODIS)
}

\author{
Michael Sift, Sophia Wagner and Martin Hessling \\ Ulm University of Applied Sciences, Albert-Einstein-Allee 55, 89081 Ulm, Germany \\ Corresponding author's email: hessling@hs-ulm.de
}

\begin{abstract}
In many developing countries no infrastructure for providing people with microbiological safe drinking water exists. This demands for decentralized water disinfection that is inexpensive and requires no consumables. The casualties are often recommended the application of SODIS for drinking water treatment. There are numerous scientific studies on this disinfection method, which however are still leaving questions on the mode of functioning which is often reduced to the effect caused by the UV part of the solar radiation and there is almost no discussion in the literature what happens to the disinfected water after the SODIS treatment.

In this paper disinfection experiments with Escherichia coli in isotonic saline solutions and real surface water are performed for a set of realistic conditions for UVA irradiation and for heating but separated from each other. The results confirm that SODIS is based on the combined effect of UVA radiation and increased temperature. Further experiments lead to the recommendation that once disinfected water should be consumed without a large delay, otherwise the germ concentration rises again.
\end{abstract}

Keywords: SODIS; water disinfection; UVA radiation; thermal disinfection; water storage

\section{Introduction}

Clean, germ-free water is taken for granted in industrialized countries. This is mainly achieved by a highly developed water treatment and close supervision. The infrastructures have been built up over decades but they are costly to maintain and require skilled professionals for the technical development and maintenance.

Many developing and emerging countries have no or only regional infrastructures for water treatment and distribution. In 2011 the worldwide number of people without access to clean drinking water was about 768 million (WHO/UNICEF, 2012). The existing infrastructure for water treatment and distribution is usually only found in urban areas but the population in rural areas is not connected to any public water supply system because of the costs of its construction and maintenance.

The results of a lack of microbial safe drinking water can be fatal, especially for children and people with weakened immune system. According to estimates by UNICEF 3000 children die every day from the consequences of preventable diarrheal diseases because they have no access to disinfected drinking water. This causes more victims than
AIDS, tuberculosis and malaria together (WHO/UNICEF, 2012).

The need to give all people access to microbiological clean drinking water, calls for a low cost decentralized water disinfection. The use of filters or chemical disinfectants like Chlorine would be well-known disinfection techniques (Tayeh et al., 1996) but both approaches require consumable that are expensive and not always available.

\section{SODIS - Facts}

The so far only water disinfection method that is available everywhere and requires no consumables is the SODIS (Solar Water Disinfection) method proposed in 1980 (Acra et al., 1980), even though according to Baker similar techniques have already even been performed in India 2000 years ago (Baker, 1948).

For performing the SODIS procedure and inactivating microorganisms germ-infested water is filled in a PET bottle and exposed to solar radiation for at least 6 hours. It is assumed that the UVA part of the solar emission $(320 \mathrm{~nm}$ $-400 \mathrm{~nm}$ ) delivers the main contribution to the disinfection process (Davies and Evison, 1991; Wegelin et al., 1994; Ubomba et al., 2009; Bosshart et al., 2010). The effect of the accompanying solar heating is known to be quite high for water temperatures above $50{ }^{\circ} \mathrm{C}$, that are only seldom 
reached, but for water temperatures below $50{ }^{\circ} \mathrm{C}$ its contribution to the disinfection success is usually neglected or believed to be of lower importance (Joyce et al.; 1996; Sommer et al., 1997; Berney et al., 2006).

The potential effectiveness of the SODIS method could be proven by numerous laboratory experiments and field tests (Boyle et al., 2008; McGuigan et al., 2011; Sommer et al., 1997) but nevertheless the acceptance and implementation of SODIS in the field has been subject of many studies with very different results. Some come to the conclusion that diarrheal diseases can significantly be reduced by the application of this disinfection technique. This is contradicted by an extensive field study (Maeusezahl et al., 2009). This research group concludes that SODIS works well in the laboratory, but is not effective in the field due to the difficult practical implementation of the SODIS procedure for the user.

\section{SODIS - Open Questions}

Even though a large number of papers on SODIS have been published there are still many open questions even concerning the UVA radiation. It is still not clarified how the UVA disinfection process takes place in the various microorganisms at the molecular level and it is not decided whether the significance of the UVA radiation is possibly overestimated.

The question of the meaning of solar heating for the disinfection success is very important. As mentioned above it is known to contribute to the disinfection procedure for temperatures above $50{ }^{\circ} \mathrm{C}$, but especially at the beginning of the SODIS procedure the water temperature is usually far away from $50{ }^{\circ} \mathrm{C}$ and even at noon this water temperature is usually not reached. Does a heating to a temperature below $50{ }^{\circ} \mathrm{C}$ nevertheless contributes to the disinfection success? The answer is not only meaningful from an academic point of view but also influence the application in the field, because a temperature dependence would probably result in a reduced effectiveness in sunny but colder areas like mountains.

Another very important question is the storage of SODIS treated water. If water is disinfected with reagents like Chlorine a "depot effect" is observed with the result that germs do not recover immediately after the disinfection procedure. SODIS treated water is very likely to be stored, because this disinfection technique doesn't work at night and because of the required minimum of 6 hour solar exposure it won't often be available until the next day's afternoon. If the disinfected water is stored for one or more days, it is an important question whether the microorganisms proliferate in this period and whether the water has to be disinfected again before consumption?

In this paper experiments with Escherichia coli (E. coli) are performed to find answers to this questions, because $E$. coli not only easy to handle but it is also one of the most important diarrheal pathogens (Huang et al., 2004). Different kinds of $E$. coli contaminated test waters are produced and these samples are either disinfected by UVA radiation or by heat or they are not disinfected at all.

\section{Materials and Methods}

For preparation of the test waters E. coli (non-pathogen strain DSM 498) is incubated in LB medium (Luria Bertani medium) in shaken flasks at $37{ }^{\circ} \mathrm{C}$. Measuring the optical density at $600 \mathrm{~nm}$ (LB medium with $E$. coli) gives a rough estimation of the bacteria concentration. In the next step the sterile test water is inoculated with the bacterial suspension. This results in an E. coli concentration of about 100000 $\mathrm{CFU} / \mathrm{ml}$ (CFU: colony forming units). More precise quantification is obtained in all experiments by membrane filtration (DIN, 2008) with filters and Endo type nutrient pads of Sartorius AG (Goettingen, Germany).

The experiments are performed with commercial, transparent 0.51 PET mineral water bottles that were emptied and disinfected for 15 min with UVC radiation prior to filling with the different test waters.

\section{UVA Radiation and Contaminated Saline Solution}

The first test water is an isotonic saline solution (distilled water with $0.9 \% \mathrm{NaCl}$ ) with an $E$. coli concentration of about $100000 \mathrm{CFU} / \mathrm{ml}$. A first bottle of this test water is placed horizontally in a standard lab incubator with two UVA lamps (MASTER Actinic BL TL-D 15W-10 G13 of Philips, Amsterdam, The Netherlands). The peak emission can be found at $367 \mathrm{~nm}$ (Fig. 1). This leads to an average UVA irradiation density of about $4 \mathrm{~mW} / \mathrm{cm}^{2}$ or $40 \mathrm{~W} / \mathrm{m}^{2}$. This is a very reasonable and realistic value, because measured UVA solar irradiation values at noon under sunny conditions can also be about $40 \mathrm{~W} / \mathrm{m}^{2}$ (Pinedo et al., 2006). A second PET bottle with the same bacteria solution is coated with Aluminum foil prior to placing it in the incubator as reference sample. Both bottles stay in the incubator for 6 hours and the water temperature is measured in the beginning and in the end. The heating of the incubator was turned off during this period but the UVA lamps could influence the temperature.

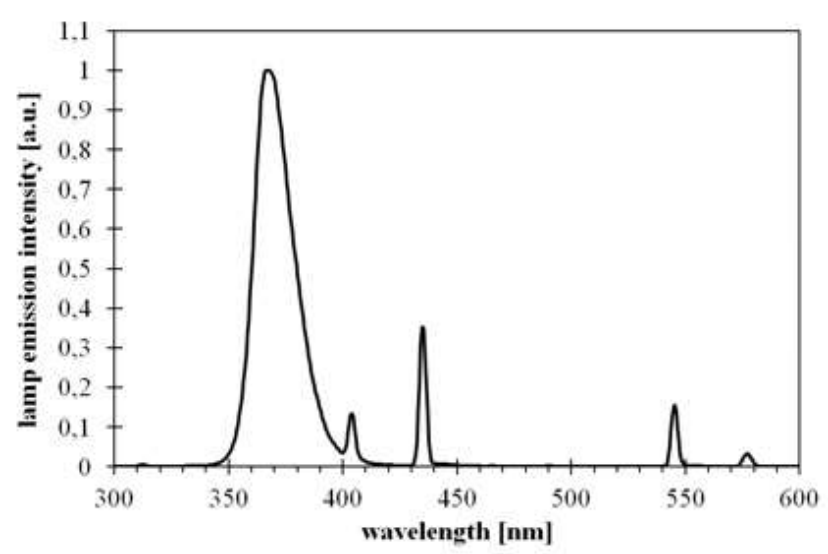

Fig. 1: Emission spectrum of employed UVA lamp. 


\section{UVA Radiation and Contaminated Surface Water}

The second test water is autoclaved surface water of a little pond in Ulm (Germany) that shows higher optical absorption compared to the clear saline solution (Fig. 2.). Again two PET bottles, contaminated with about 100000 $\mathrm{CFU} / \mathrm{ml}$ are filled with this test water. One of them gets an Aluminium foil coating and both of them are placed within the incubator with the UVA lamps and stay there for 6 hours with temperature measurements in the beginning and the end.

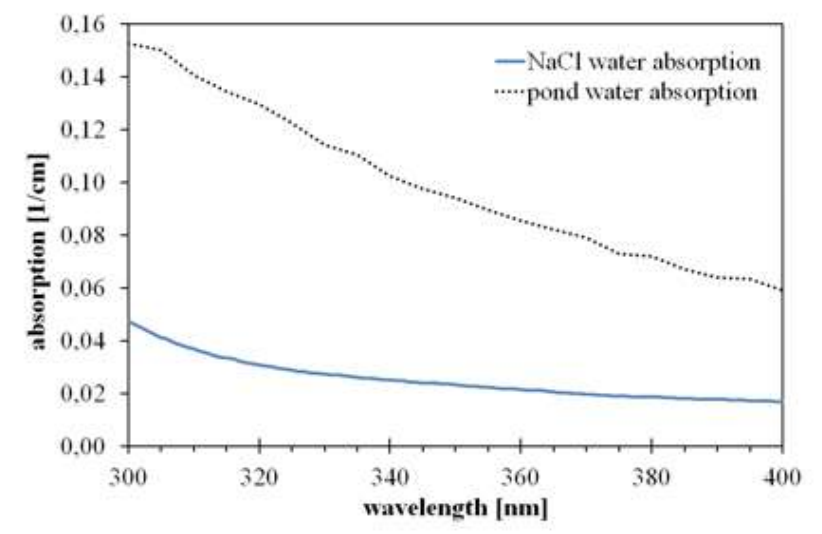

Fig. 2: Absorption spectra of $0.9 \% \mathrm{NaCl}$ solution and pond water in the spectral region 300 to $400 \mathrm{~nm}$.

\section{Increased Temperature and Contaminated Saline Solution}

It is assumed that the proposed drinking water can heat up to temperatures of above $50{ }^{\circ} \mathrm{C}$ within the SODIS treatment but this happens rarely (Berney et al., 2006). Joyce et al. report of observed water temperatures during SODIS experiments in Kenya (Joyce et al., 1996). The average starting temperature was $24.4^{\circ} \mathrm{C}$ and for the maximum temperature an average value of $45.6^{\circ} \mathrm{C}$ was reached after a few hours. Therefore once again test water of an isotonic saline solution (distilled water with $0.9 \% \mathrm{NaCl}$ ) with an $E$. coli concentration of about $100000 \mathrm{CFU} / \mathrm{ml}$ is filled in sterilized 0.5 $1 \mathrm{PET}$ bottles and subsequently the bottles are slowly heated from $25{ }^{\circ} \mathrm{C}$ within 4 hours to $48{ }^{\circ} \mathrm{C}$ in the incubator. (For technical reasons the treatment was stopped after 4 hours.)

\section{Temporal Development Of Bacteria Concentration after Disinfection}

Again an isotonic saline solution (distilled water with $0.9 \%$ $\mathrm{NaCl}$ ) with an $E$. coli concentration of about 100000 $\mathrm{CFU} / \mathrm{ml}$ is prepared. This sample is filled in previously sterilized 0.5 1 PET bottles and kept at room temperature for 6 days. At the beginning and after 2 and 6 days the bacteria concentration is measured.

A similar procedure is performed for a bottle of contaminated isotonic saline solution that was previously sterilized by 6 hours of UVA radiation as described above. The sample is stored in a fridge at $8{ }^{\circ} \mathrm{C}$. E. coli concentrations are determined by membrane filtration at the beginning and 2 days later.

Finally pond water contaminated with an $E$. coli concentration of about $100000 \mathrm{CFU} / \mathrm{ml}$ is filled in a PET bottle, exposed to UVA radiation for 6 hours and subsequently stored at room temperature before the $E$. coli concentration is determined after 6 days.

\section{Results and Discussion}

\section{UVA Radiation and Contaminated Saline Solution}

As expected, the bacteria concentration was significantly reduced by the UVA irradiation in both test waters. In the experiment with the contaminated saline solution only $2 \%$ of the E. coli survived the irradiation (Fig. 3.). This is a reduction by 1.7 log-levels. Meanwhile the bacteria concentration in the reference sample that was protected by the Aluminium foil decreased to $77 \%$. This is probably not due the observed temperature rise from $24{ }^{\circ} \mathrm{C}$ in the beginning to $29.4^{\circ} \mathrm{C}$ at the end but just a consequence of the statistic errors of the membrane filtration method.

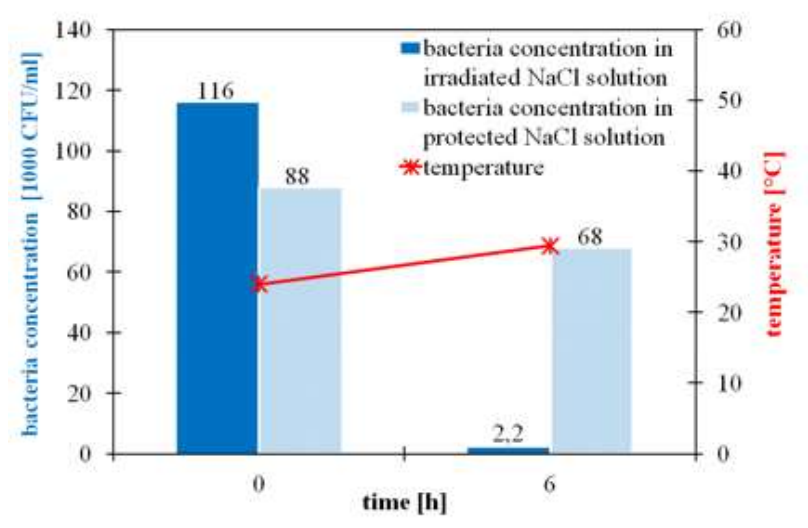

Fig. 3: Bacteria concentrations and temperatures at the beginning and the end of the UVA disinfection procedure for contaminated saline solutions.

\section{UVA Radiation and Contaminated Surface Water}

In Fig. 4 similar results for the pond water can be found. The UVA disinfection success is even higher than in the saline solution with only $0.7 \%$ surviving bacteria or an $E$. coli reduction by $2.2 \mathrm{log}$-levels. This is unexpected because of the lower optical transmission of the pond water but once again it cannot be caused by a temperature effect since the temperature only raised from $25^{\circ} \mathrm{C}$ to $31.2{ }^{\circ} \mathrm{C}$ within the 6 hours. Maybe the higher absorption presented in Fig. 2 is counterbalanced by multiple reflections and therefore longer optical path lengths for the UVA radiation. Again there is also a bacteria concentration reduction observed in the protected reference sample but this significantly differs from the concentration in the irradiated sample and may again be caused by statistical errors of the membrane filtration method. (It should be mentioned that the employed 0.51 bottle has a small diameter of $5 \mathrm{~cm}$. If larger PET bottles with larger diameter are used the UVA intensity at 
the far side of the sun may be considerably lower, resulting in a reduced disinfection success.)

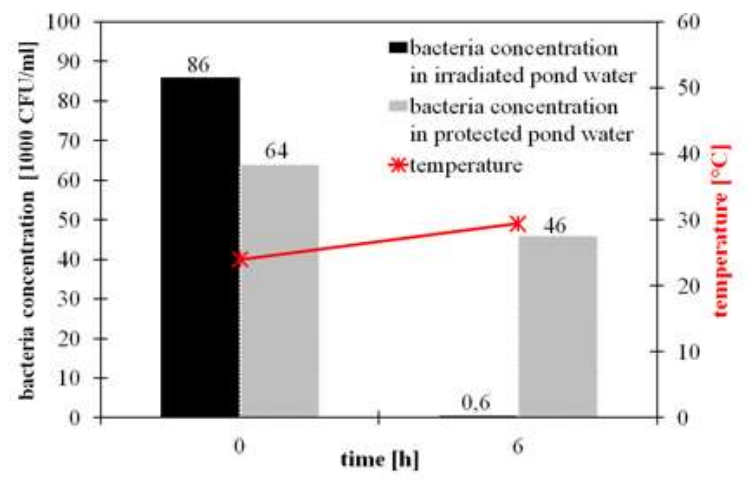

Fig. 4: Bacteria concentrations and temperature at the beginning and the end of the UVA disinfection procedure for contaminated pond water.

The disinfection success of 1.7 and $2.2 \log$-levels may be impressive at first glance, but the applied UVA dose of 86.4 $\mathrm{J} / \mathrm{cm}^{2}$ (6 hours of $40 \mathrm{~W} / \mathrm{m}^{2}$ ) is optimistic and might not be reached under cloudy conditions. Furthermore there are microorganisms which are more resistant to UVA radiation than $E$. coli and in international standards for water disinfection with UVC radiation a 5 log-level reduction (DIN, 2007) is demanded.

So disinfection merely performed by solar UVA emissions probably wouldn't be sufficient for the production of safe drinking water.

\section{Increased Temperatures and Contaminated Saline \\ Solution}

The results of the slow heating from $25^{\circ} \mathrm{C}$ to $48^{\circ} \mathrm{C}$ can be found in Fig. 5. Under the described conditions an E. coli reduction of $1.3 \mathrm{log}$-levels is reached. This is a significant disinfection contribution but lower than the contribution caused by the UVA radiation. However, it should be considered that the sample was heated here for only 4 hours due to technical reasons. For a duration of 6 hours the disinfection contribution of heating would have been expected to be larger. Sometimes there even may be conditions, e.g. in very hot but cloudy weather, when the heating contribution to the disinfection equals the radiation part.

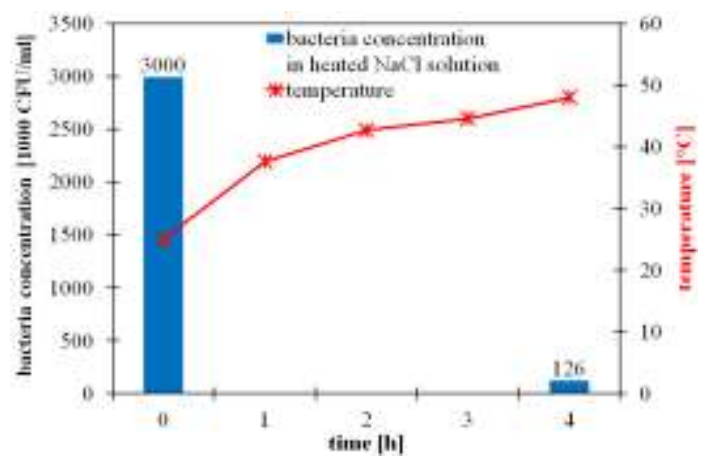

Fig. 5: Bacteria concentration and temperature for a mere heating disinfection of a contaminated $\mathrm{NaCl}$ solution.

\section{Temporal Development of Bacteria Concentration after Disinfection}

The question whether once disinfected water stays more or less germ-free, is one of the most important topics for the application of SODIS in the field.

The bacteria concentration development of the nondisinfected E. coli contaminated saline solution at room temperature is depicted in Fig. 6. Though the nutrient concentration in the saline solution is quite low - and therefore limits the germ proliferation - the E. coli concentration increases by one order of magnitude within 2 days and even by a factor of 30 within 6 days.

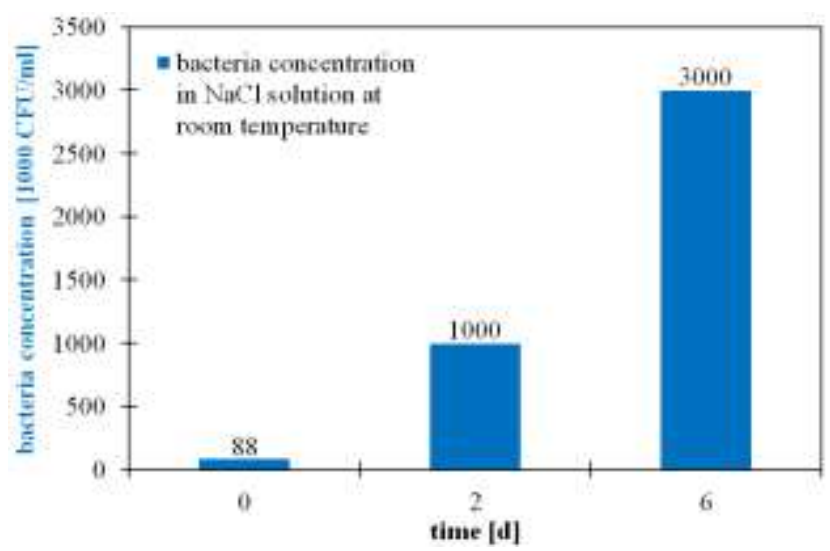

Fig. 6: Temporal development of bacteria concentration for a contaminated but not not-disinfected $\mathrm{NaCl}$ solution.

It can be expected that the regrowth of the bacteria concentration could be even more distinct for the contaminated and disinfected pond water, because the effect of nutrient limit is lower for lower $E$. coli starting concentrations.

This is demonstrated in Fig. 7 for previously disinfected surface water. Though the starting concentration in this disinfected test water is more than a factor of 100 lower than in the untreated bacterial solution in Fig. 6, after 6 days the concentration is even higher in the formerly disinfected water and more than 50 times higher than the bacterial starting concentration prior to disinfection!

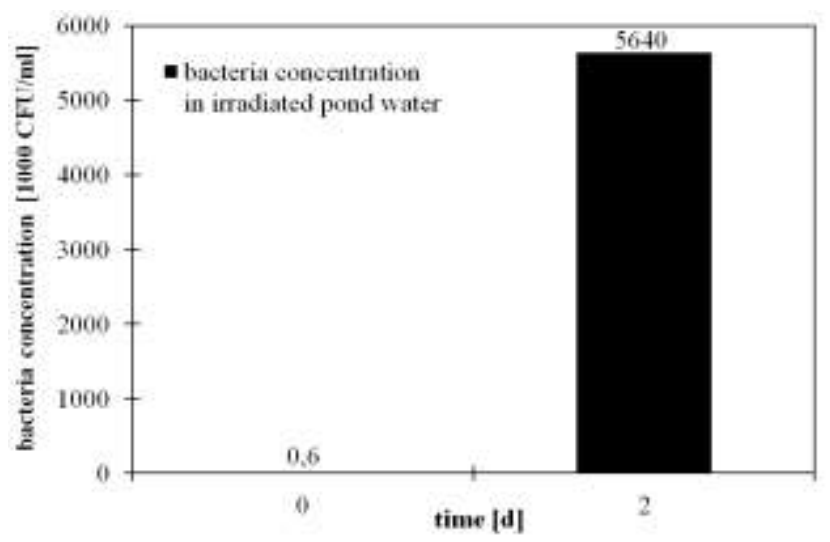

Fig. 7: Temporal development of bacteria concentration for disinfected pond water solution. 
This proves that SODIS offers no depot effect. Treated water doesn't stay more or less germ-free but the low number of bacteria that survived the disinfection procedure recovers very fast and reaches the original germ concentration within a period that is much shorter than 6 days.

So the water that was disinfected by the SODIS method should be consumed within hours or otherwise it has to be cooled to avoid bacterial recovery as is successfully demonstrated in Fig. 8 for disinfected water that was stored at $8{ }^{\circ} \mathrm{C}$ in a fridge which even lead to a further bacterial reduction.

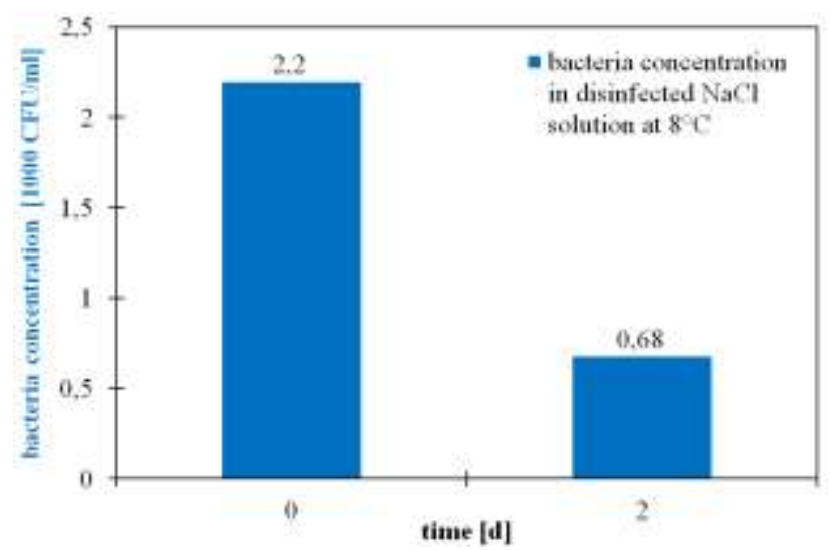

Fig. 8: Temporal development of bacteria concentration for a disinfected $\mathrm{NaCl}$ solution at $8{ }^{\circ} \mathrm{C}$.

\section{Conclusions}

The presented experiments and results are preliminary and incomplete with regard to the many open questions. More experiments would have been desirable to simulate the many more different applications and conditions - like different PET bottle sizes, water qualities, germs, thermal and radiation conditions.

Nevertheless a set of reasonable conditions was chosen and with $E$. coli one of the most important microorganisms for water borne infections was selected.

The performed investigations provide a good impression of important SODIS aspects. As expected the UVA radiation is the main contributor for the disinfection process but the mere radiation doesn't guarantee a high disinfection success. The disinfection effect of heating is lower but may be in the same order of magnitude - or even higher under hot conditions.

One of the largest practical problems of SODIS is probably the topic of storing disinfected water, because SODIS shows no depot effect. The typical SODIS user usually has no cooling capacities, so he should consume the disinfected water within hours. Otherwise if the disinfected water is stored for days the disinfection becomes useless because the bacterial concentration becomes as high as it was before performing the SODIS procedure.

\section{References}

Acra A, Karahagopian Y, Raffoul Z and Dajani R (1980) Disinfection of oral rehydration solutions by sunlight. Lancet 2(8206): 1257-1258. DOI: 10.1016/S01406736(80)92530-1

Baker MN (1948) The quest for pure water. The history of water purification from the earliest records to the twentieth century. American Water Works Assn. (New York, USA)

Berney M, Weilenmann HU, Simonetti A and Egli T (2006) Efficacy of solar disinfection of Escherichia coli, Shigella flexneri, Salmonella Typhimurium and Vibrio cholera, $J$. Appl. Microbiol. 101(4): 828-836. DOI: 10.1111/j.13652672.2006.02983.x

Bosshard F, Bucheli M, Meur Y and Egli T (2010) The respiratory chain is the cell's Achilles' heel during UVA inactivation in Escherichia coli. Microbiology 156: 2006-2015. DOI: 10.1099/mic.0.038471-0

Boyle M, Sichel C, Fernández-Ibáñez P, Arias-Quiroz GB, IriartePuña M, Mercado A, Ubomba-Jaswa E and McGuigan KG (2008) Bactericidal effect of solar water disinfection under real sunlight conditions. Appl. Environ. Microbiol. 74(10): 2997-3001. DOI: 10.1128/AEM.02415-07

Davies CM, Evison LM (1991) Sunlight and the survival of enteric bacteria in natural waters. J. Appl. Bacteriol. 70(3): 26574. DOI: 10.1111/j.1365-2672.1991.tb02935.x

DIN Deutsches Institut für Normung e.V. (2007) DIN EN 14897:2007-09: Water conditioning equipment inside buildings - Devices using mercury low-pressure ultraviolet radiators - Requirements for performance, safety and testing. Beuth (Berlin, Germany)

DIN Deutsches Institut für Normung e.V. (2008) DIN EN ISO 8199: 2007 Water Quality-General Guidance on the Enumeration of Microorganisms by Culture. Beuth (Berlin, Germany)

Huang, DB and DuPont HL (2004) Enteroaggregative Escherichia coli: An emerging pathogen in children. Semin. Pediatr. Infect. Dis. 15: 266-271. DOI: 10.1053/j.spid.2004.07.008

Joyce TM, McGuigan KG, Elmore-Meegan M and Conroy RM (1996) Inactivation of fecal bacteria in drinking water by solar heating. Appl. Environ. Microbiol. 62(2): 399-402.

Maeusezahl D, Christen A, Pacheco GD, Tellez FA, Iriarte M, Zapata ME, Cevallos M, Hattendorf J, Cattaneo MD, Arnold B, Smith TA and Colford JM (2009) Solar drinking water disinfection (SODIS) to reduce childhood diarrhoea in rural Bolivia: a cluster-randomized, controlled trial. PLoS Med. 6(8): e1000125. DOI: 10.1371/journal.pmed.1000125

McGuigan KG, Samaiyar P, du Preez M and Conroy RM (2011) High compliance randomized controlled field trial of solar disinfection of drinking water and its impact on childhood diarrhea in rural Cambodia. Environ. Sci. Technol. 45(18): 7862-7867. DOI: 10.1021/es201313x

Pinedo JL, Mireles F, Ríos C, Quirino LL and Dávila JI (2006) Spectral signature of ultraviolet solar irradiance in Zacatecas. Geofísica Internacional 45(4): 263-269. 
Sommer B, Marino-Enriquez A, Solarte Y, Salas ML, Dierolf C and Valiente C (1997) SODIS - An Emerging Water Treatment Process. J. Water SRT-Aqua 46(3): 127-137.

Tayeh A, Cairncross S and Maude GH (1996) The impact of health education to promote cloth filters on dracunculiasis prevalence in the northern region, Ghana. Soc. Sci. Med. 43(8): 1205-1211. DOI: 10.1016/0277-9536(95)00383-5

Ubomba-Jaswa E, Navntoft C, Polo-López MI, Fernandez-Ibáñez $P$ and McGuigan KG (2009) Solar disinfection of drinking water (SODIS): an investigation of the effect of UV-A dose on inactivation efficiency. Photochem. Photobiol. Sci. 8(5): 587-595. DOI: 10.1039/b816593a

Wegelin M, Canonica S, Mechsner K, Fleischmann T, Pesaro F and Metzler A (1994) Solar water disinfection: Scope of the process and analysis of radiation experiments. $J$. Water SRT-Aqua 43(4): 154-169.

WHO/UNICEF (2012) Joint Water Supply and Sanitation Monitoring Programme: Progress on Drinking Water and Sanitation. WHO/UNICEF (Geneva, Switzerland; New York, USA) 